\title{
METHODOLOGICAL APPROACH TO THE EVALUATION OF AGRICULTURAL BUSINESS SYSTEM FLEXIBILITY
}

\author{
Skydan O. ${ }^{1}$, Nykolyuk O. ${ }^{2}$, Pyvovar P. ${ }^{3}$, Martynchuk I. ${ }^{4}$ \\ ${ }^{1} \mathrm{ScD}$. Zhytomyr National Agroecological University, Zhytomyr, Ukraine. \\ Tel. +38098 7174837. E-mail skydano@ukr.net \\ ${ }^{2}$ ScD. Zhytomyr National Agroecological University, Zhytomyr, Ukraine. \\ Tel. +38098 4563234. E-mail nikolyukolya@gmail.com \\ 2 PhD. Zhytomyr National Agroecological University, Zhytomyr, Ukraine. \\ Tel. +38097 4682195. E-mail symon-pyvovar@ukr.net \\ ${ }^{3} \mathrm{PhD}$. Zhytomyr National Agroecological University, Zhytomyr, Ukraine. \\ Tel. +38067 2579733. E-mail martynchuk.ivan@ gmail.com
}

Received 0410 2019; accepted 20122019

\begin{abstract}
Agricultural business depends not only on financial and economic factors, but also on natural and climatic conditions, which necessitates continuous development, which is based on adaptation to unpredictable and random conditions of the internal and external environment. The goal is to develop a methodological approach to assessing agricultural business system flexibility, which will provide an opportunity to study the ability of agricultural producers of various sizes to adapt to unpredictable changes, taking into account the internal and external environment. On the basis of a comparative analysis of modern approaches to the definition of flexibility, a definition of the concept of "flexibility of business systems" is proposed. The method of evaluation of agricultural business system flexibility has been developed that includes operational, structural, and strategic flexibility.
\end{abstract}

Key words: agricultural business system, flexibility, operation flexibility, structural flexibility, strategy flexibility.

JEL Codes: Q01, Q12, Q14.

\section{Introduction}

In the context of uncertainty and chaotic dynamics of market conjuncture, the trend to a rapid scientific and technical development as well as the necessity to ensure innovation-oriented production, one of the key features of a business system is its flexibility. Highly flexible business systems are characterized by the ability to adapt to external impact, to form and to retain competitive advantages, to ensure efficient operation in the long term. The need to form the ability to adapt to negative external challenges as quickly as possible determines the objective need for an in-depth study of the range of problems related to the flexibility of agricultural business systems.

Copyright (C) 2019 The Authors. Published by Vytautas Magnus University. This is an open-access article distributed under the terms of the Creative Commons Attribution-NonCommercial 4.0 (CC BY-NC 4.0) license, which permits unrestricted use, distribution, and reproduction in any medium, provided the original author and source are credited. The material cannot be used for commercial purposes. 
However, owing to the fact that the notion of "business system flexibility" is multi-dimensional, multi-criterial and multi-functional, a universal definition of this term has not been created and a generally accepted methodological approach to its quantitative evaluation has not been adopted.

The goal is to develop a methodological approach to assessing agricultural business system flexibility, which will provide an opportunity to study the ability of agricultural producers of various sizes to adapt to unpredictable changes, taking into account the internal and external environment

Object - agricultural business system flexibility.

Subject - theoretical and methodological aspects of evaluation of agricultural business system flexibility.

Methodology for the investigation of business system flexibility is based on the consistent substantiation of three components: 1) notional concept of the term "business system flexibility", which reflects its definition, content, comparison with other features of economic systems close in meaning; 2) integral concept of flexibility of economic agents; 3) methodology for the quantitative evaluation of flexibility. According to such methodological approach, it is necessary to define the notion of "business system flexibility" within the framework of this research, and also to identify the components of the concept of business system flexibility and to develop the methodology for evaluating the flexibility degree taking into account its conceptual foundations.

\section{Results}

The procedure of terminological analysis, which consists of three stages, is the basis for the substantiation of the definition. At the first stage, the visualization of the list of words and categories that reflect the content of the investigated notion is carried out with the help of a cloudword. In order to do that, the most common definitions are analyzed and the number of the repetitions of one and the same word in all definitions is calculated. The results are presented visually following the principle: the more often a word is repeated, the bigger is its font size and the closer it is to the center of a cloudword. As a result, key words are selected out of all definitions; further terminological analysis of the notion "flexibility" is carried out in their context.

At the second stage, there is identification and critical analysis of the most used generic notions of flexibility. Generic notion is a notion that reflects essential features of a class of objects which belong to the closest genus of the investigated notion (Kondakov, 1975, p. 519). The closest genus is a wider class of phenomena which comprises the investigated notion as a genus (Kondakov, 1975, p. 70). The final stage includes generalization of the most distinctive features of business system flexibility that have to be considered in the further evaluation of its degree. 
Only one term, namely flexibility is used in the domestic and Russian economic literature in the context of the issues under investigation, while in Englishlanguage sources, there are two of them - "flexibility" and "agility". Therefore, cloudwords are built in the context of two languages. The term "capability" ( $46 \%$ of the investigated definitions) and "ability" (38\%) are used as a generic notion in the overwhelming majority of Ukrainian and Russian sources (Komarynets, 2013, p. 116; Hrachev, 2006, p. 5; Hlaholev, 2002, p. 10; Zhukov, 2007, p. 10-111; Lepeiko, 2012; Shatilova, 2014, p. 83; Demkiv, 2014, p. 13). The term "adaptability" is used much less frequently (15\%) (Lavrentieva, 2015, p. 124; Hryniova, 2013, p. 25) (Fig. 1). The word "capability" in this case is for the most part a Ukrainian translation of the Russian word "ability" (Hrachev, 2006, p. 5; Hohalev, 2002, p. 10; Zhukov, 2007, p. 10-11).

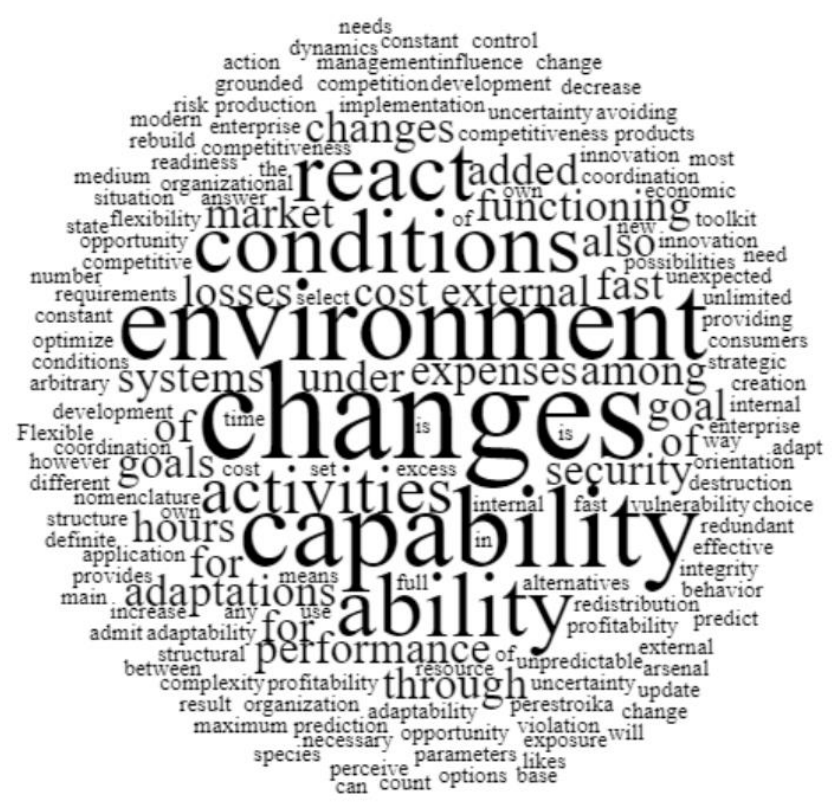

Fig. 1. Cloudword for the definitions of the term "flexibility" (Ukrainian source)

Among the generic notions used to define the term "agility", the most frequent term in the English language literature is "ability" (64\%) and much less frequent are "capacity" (14\%) and "capability" (14\%) (Fig. 2). Similarly, two generic notions are used in the definitions of the English term "flexibility", namely "capacity" (50\%) and "ability" (33\%) (Fig. 3). These three terms are also translated in a general sense as the ability (capability) to perform certain actions. However, the substantial difference between the interpretations of these words is that the ability in the meaning of "ability" reflects the actual capabilities of the business system and the ability to perform specific actions. Instead, the term "capability" is associated with the potential of such abilities and capabilities of a business system. A distinctive feature of the word "capacity" is that it is associated with the quantitative component of the ability. In terms of context, "capacity" answers the question "how much", while 
"ability" and "capability" answer the question "whether a business system is able to perform certain actions or not". Taking into account the peculiar features of the business system flexibility, the term "ability" should be used for its definition. It reflects the actual realized, rather than the potential ability (capability) to adapt.

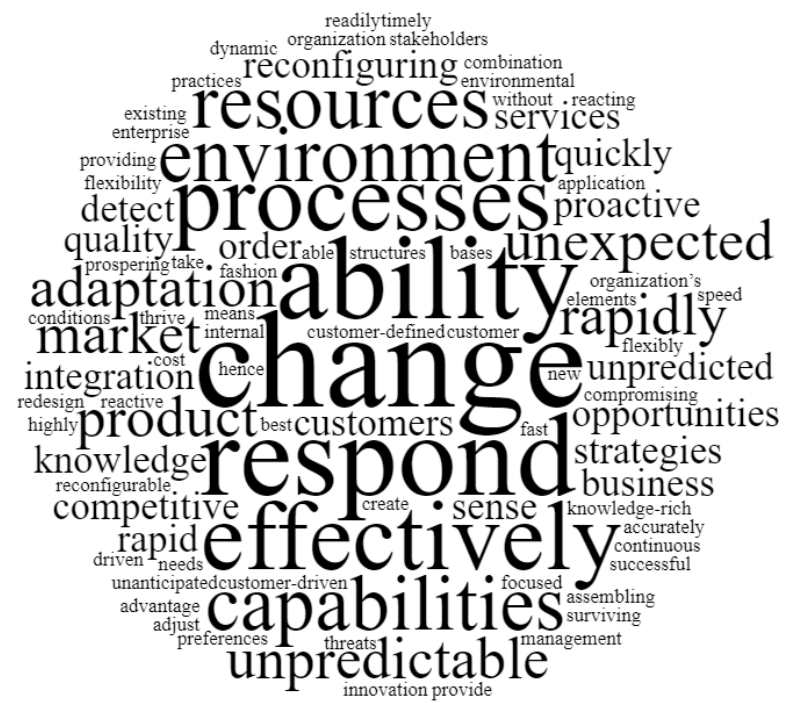

Fig. 2. Cloudword for the definitions of the term "agility"

When considering the causal relationship between ability (or capability) and flexibility, the ability (here - the ability to adapt to certain conditions) provides flexibility and therefore is primary. Against this background, flexibility cannot be the ability. On the other hand, having certain ability, a business entity may use it not fully. That is, a business system may be able to adapt, but for a number of reasons it does not. Then it can be asserted that a business entity can be either flexible or inflexible. The decisive factor is not the presence of ability (capability), but how effectively and fully it is realized.

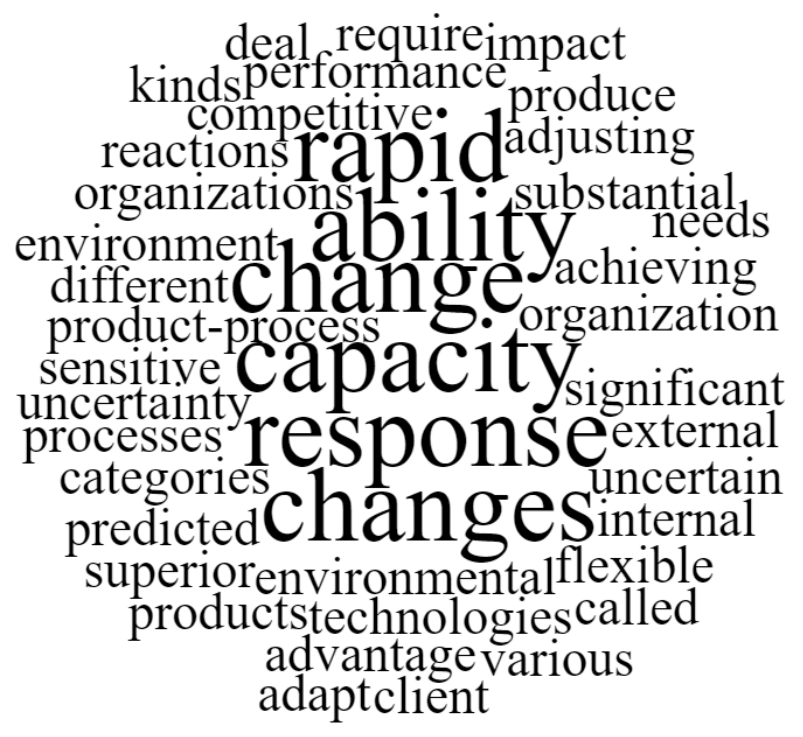

Fig. 3. Cloudword for the definitions of the term "flexibility" (English source) 
Flexibility can also be defined as a property or characteristic of a system (Kuznetsov, 2000). Property is a special, distinctive feature of an object; its essential feature. On the one hand, the characteristic determines if an object belongs to a particular class. On the other hand, it is used to specify this object and to compare it with other objects (Baranova, 2007). Under modern conditions of uncertainty, flexibility is inherent in all business systems, but its degree can vary from zero (inflexible enterprise). That is, business systems vary in terms of flexibility, and therefore it can be considered a criterion for comparing business entities.

So, firstly, flexibility is a feature common to all business systems that unites them into a separate class - the "business system" class. Secondly, the quantitative evaluation of flexibility is a criterion for comparing business systems and differentiating inflexible systems, business systems with low, medium, and high degrees of flexibility. Then, it can be argued that flexibility is used to specify the status of specific business system in comparison with other business entities. Therefore, the generic notion of business system flexibility is the term "characteristic", not the property.

At the next stage of terminological analysis, it is necessary to identify peculiarities and distinctive features of flexibility that distinguish it from other characteristics of business systems. First of all, it should be noted that although flexibility is not the ability, they are related, as evidenced by absolutely all the definitions previously mentioned. According to the constructed cloudwords (Fig. 1$3)$, the abilities to "response" (31\%) or to "adapt" (23\%) are most often found in the definitions of flexibility.

The distinctive feature of these abilities is that the reaction is not always adequate and sufficient to ensure the survival and development of the system. Adaptation also implies the transition of a business system to the condition that is at least not worse than before. In addition, taking into account the current need for identifying potential threats in a timely manner (better before competitors), consideration of the ability to foresee future changes is also important (Shatilova, 2014, p. 83; Gunasekaran, 1999).

Changes to which the business system has to adapt relate to a particular environment (external, internal, competitive). Overall, external challenges require rapid response, but in some cases, negative changes occur within the system. This is especially true for complex vertically integrated structures, whose participants may eventually cease to meet the interests of the majority.

Taking this into account, while defining flexibility, it is expedient to consider changes in the economic environment, which combines both internal and external influences (Kamarynets, 2013, p. 116). Since the flexibility of business entities concerns not only the survival but also the development, it is fundamentally important not only to provide a quick (as stated by (Kidd, 1994; Gunasekaran, 1999; Simpson, 1989, p. 414; Sambamurthy, 2003), but also effective (which is not always fast) (Shatilova, 2014, p. 83; Simpson, 1989, p. 414) and timely adaptation. 
When researchers talk about the reaction or adaptation to negative conditions, researchers mean the change of existing system parameters, including product, business processes (Simpson, 1989, p. 414); resources, processes, knowledge (Sambamurthy, 2003); resources, processes and strategies (Mathiassen, 2006); processes, product and abilities. However, in our opinion, the specification of the list of objects that are transformed during the adaptation of business systems significantly limits the definition of the concept of flexibility and reduces the level of its universality. If for some entities it is enough to change only one of these elements, others need a complete structural transformation. Therefore, it is better not to specify the object of change in determining the flexibility.

Some definitions of flexibility provide a characteristic of the changes that a business system has to respond to in a timely and effective manner. New, rapid, unpredictable conditions or uncertainty are usually mentioned in domestic sources, while in English ones unexpected and unpredictable conditions are considered. As for the unexpectedness of changes, the ability to predict potential changes and to adapt to them earlier than competitors is one of the main features of flexibility. Therefore, ideally, business systems should expect changes.

Uncertainty is an objective characteristic of the external and internal environment of a business entity, the existence of which is caused by the inability to obtain complete and accurate knowledge about a particular problem. Uncertain changes in the environment mean the impossibility of predicting their consequences, whereas the fact of the onset of future changes is predictable. For example, the global crisis of 2008-2009 was forecast in advance, while its effects at the time of forecasting were unknown. Therefore, while defining the flexibility, attention should be focused not on unpredictable (or unexpected), but on uncertain changes.

Summarizing all above-mentioned information, it can be argued that the following aspects should be taken into account while defining the concept of "business system flexibility":

1) flexibility is a characteristic of business systems;

2) the need to ensure flexibility is determined by the need to adapt to the changes caused by the uncertainty of the environment where the systems function;

3) a flexible business system has the ability to forecast changes in the environment where it functions and to react to them effectively;

4) flexibility is not related directly to the ability to adapt, but to the realization of this ability by the system;

5) flexibility ensures the resilience of the system. Consequently, flexibility is a characteristic of a business system, which reflects the realization of the ability of a business system to predict changes in the environment where it functions and to react to them effectively, thus providing the system resilience.

The flexibility of business systems in today's environment is inextricably linked to their resilience. At first glance, these enterprise characteristics are antagonistic in that they are inherently different in nature, namely the ability to 
change rapidly, adapt to external challenges, and to stay stable for as long as possible. Psychological research has now argued that resilience is more related to the flexibility of the individual than to his or her ability to maintain a current positive state (Koole, 2015).

In economic science, resilience is considered in relation to the ability to cope with the challenges of the internal and external environment (Abeysekara, 2019). In particular, the issue of resilience and flexibility has been widely explored in the context of supply chain studies (Abeysekara, 2019; Vlajic, 2017). Jelena V. Vlajic defines resilience as one of the main components and driver of resilience (Vlajic, 2017)], while V. A. Asokan, M. Yarime, and M. Esteban define resilience as a characteristic of resilient socio-ecological systems (Asokan, 2017).

The causal link between flexibility and resilience is explained by the dynamic nature of the latter, which is emphasized. A resilient system is able to return to a steady state of equilibrium, which is possible only with the high flexibility of the system. V. A. Asokan, M. Yarime, and M. Esteban argue quite rightly that flexibility as a property of the socioeconomic system determines the formation of its robustness and ability to transform (Asokan, 2017). Only provided that both of these characteristics exist simultaneously, the system is resilient.

Flexibility is a criterion for comparing business entities with each other. This determines the need for the quantitative measurement of this complex formalized characteristic of business systems. The basis for the development of the methodology of quantitative evaluation of the degree of flexibility is the results of the analysis of existing methodological approaches through the prism of features outlined in the definition. Conditionally quantitative methods, which are used to evaluate flexibility, can be divided into objective and subjective.

Objective methods include calculation methods based on mathematical processing of the actual values of financial and economic indicators of the business system functioning. Subjective (heuristic) methods involve the use of expert evaluation and can be used in two directions:

1) for quantitative measurement of qualitative indicators that are difficult or even impossible to evaluate quantitatively;

2) to assess the importance of indicators that reflect the degree of flexibility. Obviously, the calculation methods are more accurate and more adapted to the needs of management. Table 1 shows the main disadvantages and promising directions of applying the most used methods for evaluating the flexibility of business entities, as well as the methods used for its analysis. 
Table 1. Characteristics of quantitative methods for the evaluation of business system flexibility (Developed by authors)

\begin{tabular}{|c|c|c|c|}
\hline Method & $\begin{array}{l}\text { Peculiarities of } \\
\text { application }\end{array}$ & Drawbacks & $\begin{array}{c}\text { Promising directions of } \\
\text { applying }\end{array}$ \\
\hline \multirow[t]{2}{*}{ Coefficient } & $\begin{array}{l}\text { Calculation of } \\
\text { multiplicative } \\
\text { indicators (Grachov, } \\
\text { 2005; Yarulina, 2005) }\end{array}$ & $\begin{array}{l}\text { 1. It is difficult to interpret } \\
\text { the physical content of an } \\
\text { indicator } \\
\text { 2. It is difficult to formalize } \\
\text { the interrelation between the } \\
\text { flexibility and factors that } \\
\text { determine it }\end{array}$ & - \\
\hline & $\begin{array}{l}\text { Determination of } \\
\text { partial coefficients of } \\
\text { financial and economic } \\
\text { condition (Komarynets, } \\
\text { 2009; Klebanova, } \\
\text { 2006) }\end{array}$ & \multirow{2}{*}{$\begin{array}{l}\text { 1. Prevent the possibility to } \\
\text { evaluate the ability to adapt to } \\
\text { the changes in the } \\
\text { environment } \\
\text { 2. Sometimes coefficients are } \\
\text { presented in too much detail } \\
\text { or, vice versa, some of them } \\
\text { are not considered } \\
\text { 3. Application results reflect } \\
\text { only statistical component of } \\
\text { a business system without } \\
\text { considering a dynamic one }\end{array}$} & $\begin{array}{l}\text { Calculation of partial } \\
\text { coefficients, but with } \\
\text { the subsequent } \\
\text { mathematic processing }\end{array}$ \\
\hline Index & $\begin{array}{l}\text { Normalization of } \\
\text { indicators (usually } \\
\text { coefficients), which } \\
\text { reflect flexibility of a } \\
\text { business system }\end{array}$ & & $\begin{array}{l}\text { Transformation of } \\
\text { actual values of } \\
\text { flexibility indicators in } \\
\text { non-dimensional and } \\
\text { intercomparable values }\end{array}$ \\
\hline $\begin{array}{l}\text { Integral estimation } \\
\text { (Komarynets, } \\
\text { 2012; Ignatieva, } \\
\text { 2013, p. 131; } \\
\text { Shatilova, 2010) } \\
\end{array}$ & $\begin{array}{l}\text { Integration of } \\
\text { indicators into a } \\
\text { generalized synthetic } \\
\text { flexibility coefficient }\end{array}$ & $\begin{array}{l}\text { Necessity to substantiate the } \\
\text { methodology for calculation } \\
\text { both of integral and partial } \\
\text { normalized coefficients }\end{array}$ & $\begin{array}{l}\text { Calculation of integral } \\
\text { flexibility coefficients }\end{array}$ \\
\hline \multirow[t]{3}{*}{$\begin{array}{l}\text { Heuristic (Verdú- } \\
\text { Jover, 2006, } \\
\text { c. 339-340) }\end{array}$} & $\begin{array}{l}\text { Evaluation of weight of } \\
\text { individual flexibility } \\
\text { indicators or their } \\
\text { groups }\end{array}$ & \multirow{2}{*}{$\begin{array}{l}\text { 1. High degree of subjectivity } \\
\text { 2. Poor accuracy of obtained } \\
\text { evaluations } \\
\text { 3. Difficulties with selection } \\
\text { of experts }\end{array}$} & $\begin{array}{l}\text { Using complex } \\
\text { formalized flexibility } \\
\text { indicators for the } \\
\text { evaluation }\end{array}$ \\
\hline & \multirow{2}{*}{$\begin{array}{l}\text { Expert evaluation based } \\
\text { on the sociometric } \\
\text { survey }\end{array}$} & & \multirow[t]{2}{*}{-} \\
\hline & & $\begin{array}{l}\text { High probability that experts } \\
\text { do not understand the content } \\
\text { of the notion "business } \\
\text { system flexibility" } \\
\text { sufficiently }\end{array}$ & \\
\hline $\begin{array}{l}\text { Econometric } \\
\text { (correlation, } \\
\text { regression, factor } \\
\text { analysis) }\end{array}$ & $\begin{array}{l}\text { 1. Evaluating } \\
\text { representativeness of } \\
\text { sample aggregates of } \\
\text { research objects } \\
\text { 2. Identification of } \\
\text { flexibility factors } \\
\text { 3. Evaluating the } \\
\text { impact of flexibility on } \\
\text { the efficiency of a } \\
\text { business system }\end{array}$ & $\begin{array}{l}\text { 1. Necessity to use up-to-date } \\
\text { software } \\
2 \text {. Usage purely for data } \\
\text { analysis, and not for } \\
\text { evaluating processes and } \\
\text { phenomena }\end{array}$ & $\begin{array}{l}\text { 1. Substantiation of a } \\
\text { list of indicators that } \\
\text { need to be included } \\
\text { 2. Identification of } \\
\text { flexibility factors } \\
\text { 3. Evaluating the } \\
\text { impact of flexibility on } \\
\text { the efficiency of a } \\
\text { business system }\end{array}$ \\
\hline Statistical method & Descriptive statistics & & $\begin{array}{l}\text { Analysis of the } \\
\text { obtained evaluation } \\
\text { results }\end{array}$ \\
\hline
\end{tabular}


The hierarchy of dynamic abilities is reflected in the types of flexibility of business entities, which include: operational, structural and strategic flexibility (Weerdt, 2009, p. 25-26). These types of flexibility are the objects of evaluation. Quantitative evaluation of any property of a business system is based on the indicators of this property. A significant number of researchers associate the degree of flexibility of a business entity with its financial and economic state (Klevlyn, 2003; Komarynets, 2013, Grantham, 2007). For example, evaluation of organizational flexibility by S. Komarynets comes down to the assessment of the financial state.

Traditional indicators of business activity, financial stability, liquidity, profitability is used as flexibility indicators (Komarynets, 2012, p. 75). This approach is based on the hypothesis that a flexible enterprise will always have an acceptable financial state. The disadvantages of assessing flexibility with the help of indicators of financial state are: 1) the impossibility to identify the source of flexibility of a specific business system; 2) ignoring other than financial areas of the formation of flexibility, first of all, production and management ones; 3 ) incapability to assess the ability of business systems to predict changes in the environment.

According to another approach, the flexibility indicators are determined in the process of interviewing the expert representatives of firms (i.e., based on subjective expert methods). The application of the expert evaluation method implies the following requirements: 1) a thorough check of the credibility of the results obtained and the consistency (concordation) of expert opinions; 2) experts should have a deep insight into the content of the object of evaluation; 3) minimization of the level of subjectivity of experts. Since it is very difficult or impossible to meet all of these requirements in the vast majority of cases, objective formal methods are considered to be more adapted to evaluating flexibility.

Flexibility is an integrated characteristic of a business system that combines a number of components. Typically, such components include: 1) financial, production, organizational and personnel, innovation-investment, marketing (Khlistunova, 2015, p. 48); 2) operational, structural, strategic flexibility (Weerdt, 2009, p. 114); 3) steady state, operational, structural, strategic flexibility, etc. (Volberda, 2006). Within the scope of constituents, indicators that accurately convey the content of each of the flexibility components are selected. The flexibility of a firm is often associated with the concept of "dynamic capabilities", the system of which has a hierarchical structure (Grant, 1996; Winter, 2003). Structuring of the complex of dynamic abilities is determined by the depth of adaptive changes in business systems. The basic routine business processes are adapted at the zero-level and at the operating level. Transformations based on zero-level abilities and operational abilities do not involve changes in the existing organizational structure and system objectives. The transformations within the zero-level and operational dynamic abilities include reconfiguration of the resource base, change of areas of activity, adaptation of the organizational structure, etc. (Winter, 2003; Helfat, 2007). Changes in the product range and objectives of a business system are related to structural 
abilities. Fundamental restructuring (for example, changing the strategy, the nature of interaction with competitors and contractors, etc.) are characteristic of enterprises with structural abilities. Such changes usually occur at a relatively high rate (Weerdt, 2009, p. 109).

V. Sherehiy, together with a team of researchers, divides approaches to quantification of flexibility into two groups (Sherehiy, 2007). The first group includes approaches that focus on the internal capabilities and capabilities of the enterprise. The task of the company is to identify the internal aspects (dimensions) of the enterprise, which are forms of flexibility. Thereafter, there is a reconfiguration and redirection of resources toward achieving the desired states within each flexibility aspect (Sherehiy, 2007). According to SLGoldman, R.N. Nagel, and K. Preiss, enterprise flexibility is determined by a set of dimensions that include the ability to 1) meet consumer needs, 2) cooperate to increase competitiveness, 3) anticipate environmental changes, and 4) attract the necessary manpower and information resources (Goldman , 1995).

Types of flexibility differ in terms of tools and methods which a business system uses to adapt to the changes in the environment. Operational flexibility is related to the ability of a business entity to adapt to external and internal challenges through improving the existing business processes and their adaptation to new conditions. Examples of such adaptation include the use of new technologies, types of raw materials, technical equipment, personnel development, etc. The main indicators of the operational flexibility are expenditures which either do not change (in the context of the intensification of inflation processes) or decrease during crises. Changes within the existing business processes usually lead to an increase in productivity. That is why while evaluating the degree of flexibility it is expedient to use not general expenditures, but the consumption of resources per one unit of manufactured products.

Structural flexibility is related to structural transformations at all levels of business processes. These are primarily the changes in the production structure. If financial and economic conditions become significantly worse, business systems usually respond with structural changes in the product range. It is proposed to use indicators of structural flexibility of business systems as indicators that reflect the dynamics of their production structure. Flexible business systems are able to change the production structure in the short term while preserving the stability of the system functioning or increasing it.

Strategic flexibility is related to the capability to change the strategy and the objectives of economic activity in line with the new economic environment in a timely manner. The indicators of strategic flexibility include performance indicators of business systems. As a result of implementing strategic flexibility, performance indicators may either remain practically unchanged (for example, during financial and economic crises), or increase (for example, in case of significant conjuncture 
transformations). The more global and large-scale the deterioration of the environment is, the smaller the indices of changes in the results of economic activity should be. Unlike business systems with a high degree of flexibility, inflexible systems will either experience significant deterioration in performance and have significant losses or become bankrupt.

Thus, indicators of flexibility of business systems that were defined include: 1) costs of resources per unit of manufactured products (primarily monetary and labor resources) (operational flexibility), 2) indicators of the structure of the product range (structural flexibility), 3) performance indicators - the level of profitability, profit per unit of resources used (strategic flexibility).

There are two ways to evaluate the flexibility of business systems. Each of them involves benchmarking analysis: either comparison with the flexibility of other business systems or with its own flexibility in previous periods. The first way of evaluation involves searching for characteristics and features that provide business systems with the maximum flexibility, viability and adaptability. Such studies are particularly relevant for industries characterized by heterogeneity of the composition and structure of the business sector. Typically, in the economic literature a benchmarking analysis of the flexibility of enterprises of different size is conducted (Verdú-Jover, 2006; Hunter, 1993; Sak, 2004; Weerdt, 2006). Such studies hypothesize that business entities of different size have different ability to predict changes in the environment and to adapt to them.

When preparing the sample frame for benchmarking analysis of the flexibility of business systems of different size one needs to substantiate the criteria by which large business entities are different from small ones. The determining factor for choosing such criteria is the area of economic activity. The size distribution of enterprises varies mostly depending on the number of personnel and the annual turnover. Agriculture is a specific branch; the area of agricultural land should be another classification criterion there. Comparative evaluation of the flexibility of business entities of various organizational legal forms is extremely important for a number of economic spheres. Given the popularization of the idea of horizontal and vertical integration, it is also relevant to confirm or, vice versa, to refute the hypothesis about the relatively high degree of flexibility of large integrated structures. Another criterion for distributing business systems is the economic sector.

The values of indicators of operational, structural and strategic flexibility reflect the actual state of a business system. Instead, the investigation of flexibility should be based on the analysis of the timeliness, immediacy and effectiveness of how a business system responds to negative challenges. For this purpose, the values of the flexibility indicators should be compared before and after the changes in the environment, that is, over a certain period. The evaluation period has to meet two requirements. Firstly, the changes in the environment during this period need to be fundamental (and in the vast majority negative). Secondly, absolutely all objects of the sample frame need to be forced to adapt to these changes. The period chosen for 
the investigation in the article is 2007-2012, which was the time of the global financial and economic crisis. The basis of the evaluation is the assertion that the most flexible business systems are those that are able to fully restore or even improve the results of their economic activity from the beginning of the negative environmental changes to the end of their destructive effects. It is expedient to make comparison with the help of indices of flexibility indicators. Such indices reflect relative deviations of indicators and are calculated as the ratio of the value of the indicator at the end of the period to its value at the beginning of the period.

Apart from the ability to adapt to economic transformations, the flexibility of a business system is related to the ability to predict them. In view of this, the period under investigation (2007-2012) is divided into two-time intervals: from 2007 to 2008, when the crisis was expected, and from 2009 to 2010, when business entities fully experienced its consequences. Taking such division into account, the quantitative evaluation of flexibility involves the calculation of indices for each of the outlined periods in the context of each individual indicator. The indices for 20072008 will reflect the ability to predict negative environmental changes, while indices for 2009-2010 the ability to effectively react to them.

It is important to conduct a benchmarking analysis of the variation of flexibility along with a benchmarking analysis of the degrees of flexibility of business systems that differ in certain features (in size, form of entrepreneurship, industries, etc.). For this purpose, it is expedient to use indicators of descriptive statistics. In particular, it is a mode and a median, a mean value, a mean square deviation, the coefficients of variation and semi-variation, quartile.

Another task concerning the investigation of flexibility is the identification of factors that influence its degree and the evaluation of the impact of flexibility on the performance indicators of business systems. The choice of a list of factors that may affect the flexibility of business entities should be based on the representation of the research object as a system (in this case, the operation of a business system). Only in this way one can avoid the problem of not taking into account some factors and excessive detailed elaboration of others. As a result, the probability of neglecting potentially effective sources of increasing the flexibility of a business entity will be minimized.

It is proposed to identify possible flexibility factors on the basis of methods for structural modeling using the IDEF0 methodology. IDEF0-models take into account input and output (effective) parameters of a business system, mechanisms of converting inputs to outputs and control systems. Fig. 4 shows an example of the IDEF0-model of the business process concerning the production of organic agricultural products. Rectangles feature functional blocks-subprocesses. One or more types of flexibility are formed within each block. Operational flexibility is usually related to the ability to change resource provision and production processes efficiently and in a timely manner (blocks of organic, traditional, conventional production). Structural flexibility is implemented within the management process by 
deciding on the product range and resource provision for its production. Strategic flexibility is also formed in the management block. Indicators that represent the content of the arrows that are directed to the functional blocks should be considered as potential factors for each type of flexibility (the input arrows from the left to the right - "input parameters", from the top to the bottom - managerial influences, from the bottom to the top - the mechanisms for implementing functions within the block).

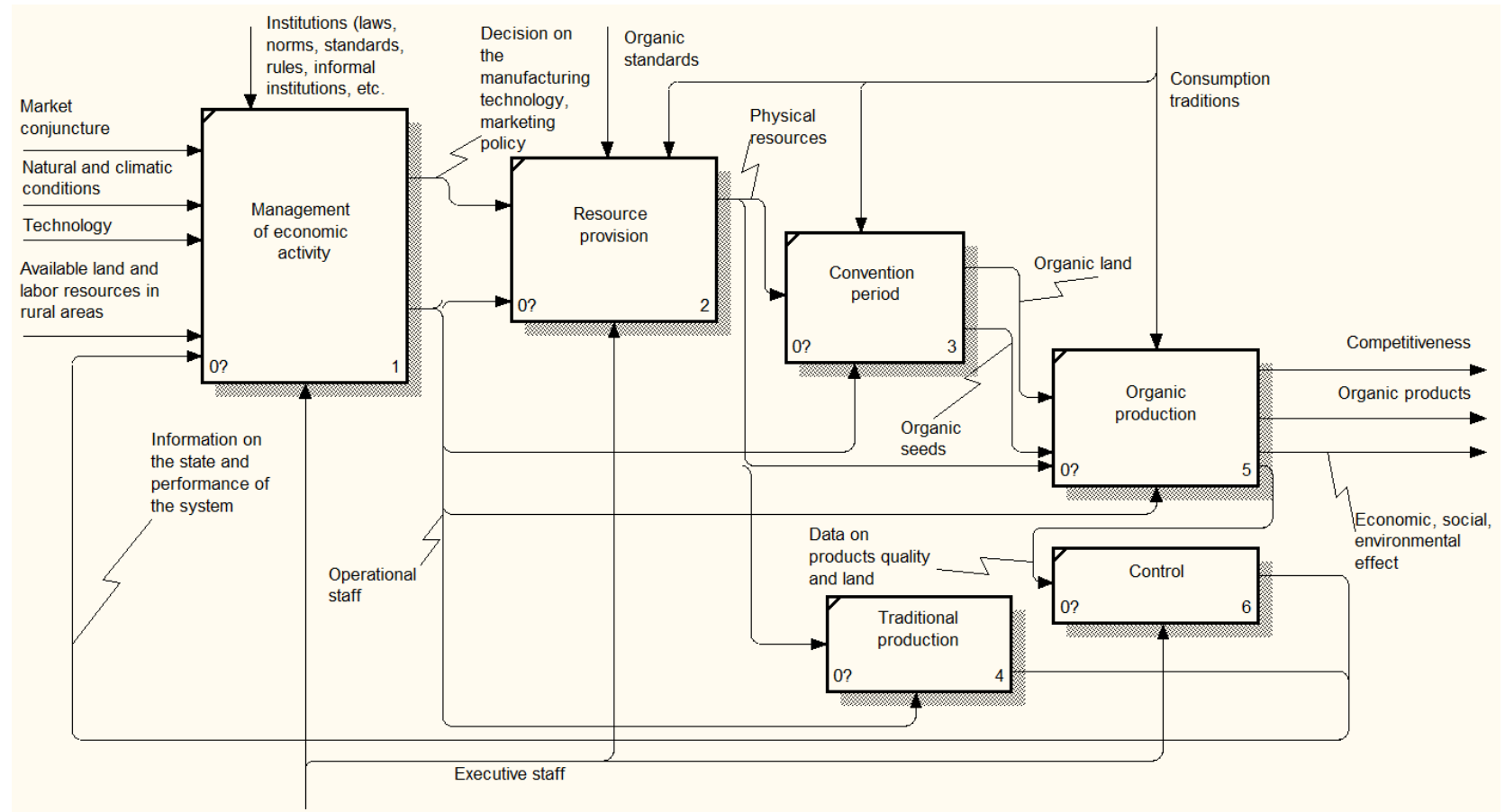

a) decomposition of the process of functioning of organic household



b) decomposition of the process of managing agricultural business system Fig. 4. IDEF0-model of the process of producing organic agricultural products 
After identifying a set of factors that can affect the flexibility it is necessary to conduct quantitative evaluation of the strength of relationship between them and the degree of flexibility. The best method for this is the correlation-regression analysis. It is important to take into account that links between some indicators may be nonlinear. Therefore, in addition to the traditional correlation coefficient and the construction of linear regression equations, it is expedient to calculate and analyze the correlation indices and to develop nonlinear regression functions.

A similar scheme is used for the study of the impact of flexibility on the effectiveness of the operation of a business system. The difference will be only that in such an analysis, flexibility indicators (operational, structural, strategic and generalized) are factor variables, while quantitative evaluations of the input parameters of the process of operation of a business system are effective indicators. For example, for organic production outputs are the level of competitiveness, quality and quantity of manufactured products, economic, social and environmental effects (Fig. 4, a).

To sum up, the methodological approach to the evaluation of the business system flexibility will be based on three procedures (Fig. 5). These procedures are determined by the objectives of quantitative measurement, which include a benchmarking analysis of the flexibility of different types of business systems, the identification of flexibility factors, the evaluation of the impact of flexibility on the efficiency of business entities. 


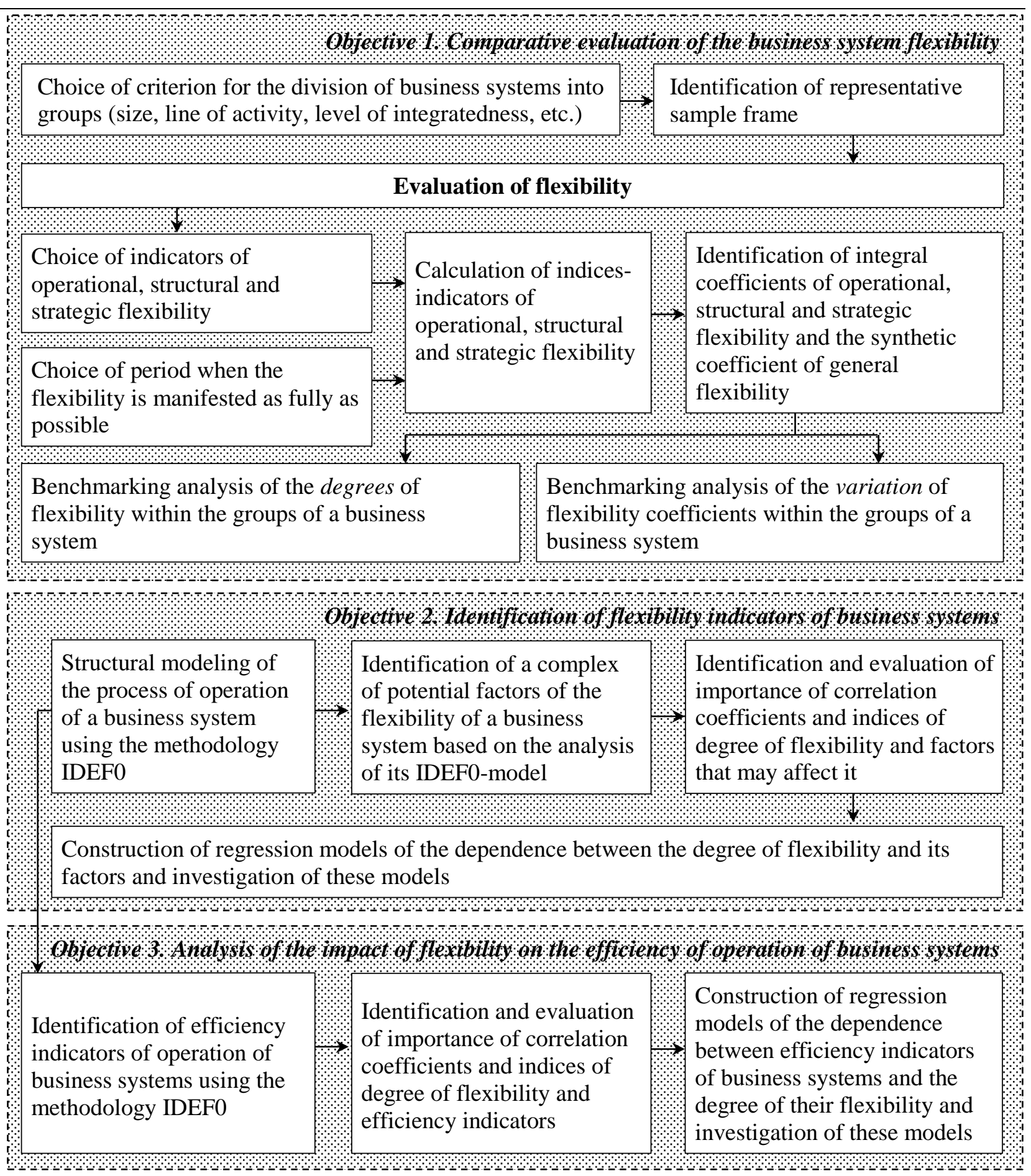

\section{Fig. 5. Methodological approach to the evaluation of the degree of business system flexibility}

Evaluation of flexibility is based on indicators of operational, structural and strategic flexibility. For the maximum objectivity of the measurement results, the flexibility indicators should be determined by means of quantitative rather than qualitative (expert) methods. Integral coefficients calculated on the basis of the indices of its indicators are quantitative evaluation of flexibility. It is expedient to use 
the methods of correlation-regression analysis in order to process the obtained results with the aim to assess the relationship between flexibility, factors affecting it and the efficiency of operation of business systems.

\section{Conclusions}

High degree of flexibility is a condition of long-term viability and sustainable development of business systems in a fast-changing, uncertain environment with chaotic nonlinear dynamics. Flexibility should be understood as the ability of a business system to predict changes in the environment of its operation and to effectively react to them. Depending on the way in which the research object adapts to the challenges of the environment, there are three types of flexibility, namely: operational, structural and strategic. Operational flexibility involves the response of a business system to changes in the environment by adapting the existing business processes without changing the nature of activities, strategies and objectives. Structural flexibility manifests itself as a change in the production structure, and strategic flexibility as a change in the strategy and objectives of the system.

The difficulty of evaluating the degree of business system flexibility is explained by its high level of abstraction and low formalism. The use of quantitative measurement methods is as informative and objective as possible; these methods are based on quantifiable indicators of the activities of economic entities, and not on expert assessments. Quantitative evaluation of operational flexibility is based on the consumption of main types of resources per unit of manufactured products. Structural flexibility is measured using indicators of production structure, and strategic flexibility with the use of indicators of the efficiency of economic activity.

The degree of flexibility should reflect how well a business system is able to adapt to changes in the environment. Therefore, the evaluation process should be based not on values of indicators of operational, structural and strategic flexibility in a particular period, but on their change over a certain period of time. Such a change should be calculated in the form of indices. The evaluation period should be the period during which fundamental structural changes occurred (mostly on a global scale). For example, the period of financial and economic crises. Business systems that are considered to be flexible have the following characteristics: a) the indices of the indicators of strategic flexibility during the crisis did not deteriorate, or even became better; $b$ ) the indices of structural flexibility are characterized by significant changes; c) the indicators of operational flexibility (expenditures indices) are constant (or as much as possible lower than inflation rate), or less than 1 .

There are three objectives of the evaluation of business system flexibility. Firstly, it is a benchmarking analysis of the flexibility of business systems that differ in certain ways (for example, in size, form of entrepreneurship, industries, etc.). It is recommended to use the integral estimation method for this analysis. Secondly, the goal of evaluating flexibility can be to determine the factors that affect it. And, thirdly, the quantitative measurement of flexibility can be done to determine how it 
affects the operation of the system. In both latter cases, it is expedient to use the methodology for structural modeling IDEF0 and the correlation-regression analysis toolkit.

\section{References}

Abeysekara, N., Kuruppuarachchi, D. (2019), Effect of supply-chain resilience on firm performance and competitive advantage: A study of the Sri Lankan apparel industry, Business Process Management Journal.

Asokan, V. A., Yarime, M., and Esteban, M. (2017), Introducing Flexibility to Complex, Resilient Socio-Ecological Systems: A Comparative Analysis of Economics, Flexible Manufacturing Systems, Evolutionary Biology, and Supply Chain Management, Sustainability.

Baranova, A. Slovar-tezaurus sovremennoi russkoi ydyomatyky: okolo 8000 ydyom sovremennoho russkoho yazyka. Moskva: Myr эntsyklopedyi Avanta+, 2007. 1135 s. http://www.jiport.com/?sname=tez [2019 03 20].

Demkiv, I. (2014). Analiz mozhlyvostei i mezh hnuchkosti pidpryiemstv spyrtovoi haluzi v umovakh rynkovoi nestabilnosti // Visnyk Ternopilskoho natsionalnoho ekonomichnoho universytetu. Vyp. 1: 130-138.

Goldman, S.L., Nagel, R.N. and Preiss, K. (1995), Agile Competitors and Virtual Organizations: Strategies for Enriching the Customer, Van Nostrand Reinhold, New York, NY.

Grant, R. (1996). Prospering in dynamically-competitive environments: Organizational capability as knowledge integration // Organization Science. 7(4): 375.

Grantham, Ch. E., Ware J. P., Williamson, C. (2007). Corporate agility : a revolutionary new model for competing in a flat world. - New York: AMACOM. 275 (XII) p.

Gunasekaran, A. (1999). Agile manufacturing: a framework for research and development // International Journal of Production Economics. Vol. 62. No. 1/2: p. 87-105.

Helfat, C., Finkelstein, S., Mitchell, W., Peteraf, M., Singh H., Teece, D., Winter, S. (2007). Dynamic Capabilities: Understanding Strategic Change in Organizations. - Malden, MA: WileyBlackwell. $160 \mathrm{p}$.

Hlaholev, S. (2002). Formyrovanye эkonomycheskoho mekhanyzma hybkoho razvytyia promyshlennoho predpryiatyia: Avtoref. dys. kand. эkon. nauk: 08.00.05. - Эkonomyka y upravlenye narodnym khoziaistvom: эkonomyka, orhanyzatsyia y upravlenye predpryiatyiamy, otrasliamy, kompleksamy - promyshlennost. - Belhorod. $180 \mathrm{~s}$.

Hrachev, A. (2005). Teoretycheskye predposylky razvytyia hybkosty predpryiatyia // Upravlinnia rozvytkom. № 1: 101-106.

Hrachov, O. (2006). Upravlinnia rozvytkom hnuchkosti pidpryiemstva: avtoref. dys. na zdobuttia nauk. stupenia kand. ekon. nauk : spets. 08.06.01. - Kharokiv. 23 s.

Hryniova V., Hrebnieva, I. (2013). Doslidzhennia sutnosti upravlinnia zminamy v zabezpechenni tsyklichnoho rozvytku pidpryiemstv // Biznes Inform. № 12: 49-254.

Hunter, L., McGregor, A., Maclnnes J., SprouU U. (1993). The Flexible Firm: Strategy and Segmentation. British Journal of Industrial Relations,31:3.

Ihnatieva, I., Khlistunova, N. (2013). Metodychni pidkhody do otsiniuvannia rivnia stratehichnoi hnuchkosti pidpryiemstv sfery posluh // Aktualni problemy ekonomiky. № 4: 128135.

Khlistunova, N. (2015) Osoblyvosti obchyslennia parametriv stratehichnoi hnuchkosti pidpryiemstv pobutovoho obsluhovuvannia // Ekonomika ta derzhava: mizhnarodnyi naukovopraktychnyi zhurnal. № 2: 47-50. 
Kidd, P.T., (1994). Agile Manufacturing: Forging New Frontiers. Addison-Wesley Reading, MA. 388 p.

Klebanova, T., Hurianova, L., Bohonykolos, N. y dr. (2006). Modelyrovanye fynansovykh potokov predpryiatyia v uslovyiakh neopredelennosty. Monohrafyia. - Kharkov: Inzhek. $312 \mathrm{~s}$.

Klevnyn, A. (2003). Orhanyzatsyia harmonychnoho proyzvodstva (teoryia y praktyka) uch. posob. - Moskva : Omeha-L. $360 \mathrm{~s}$.

Komarynets, S. (2009). Vzaiemodiia mizh orhanizatsiinoiu hnuchkistiu ta minlyvistiu seredovyshcha vzdovzh lantsiuha stvorennia vartosti // Naukovyi visnyk NLTU Ukrainy. Vyp. 19.2: 219-225.

Komarynets, S. (2012). Finansovo-ekonomichne otsiniuvannia orhanizatsiinoi hnuchkosti pidpryiemstva // Investytsii: praktyka ta dosvid. № 5: 74-77.

Komarynets, S. (2013). Chynnyky vplyvu na hnuchkist orhanizatsii // Problemy formuvannia ta realizatsii konkurentnoi polityky : materialy III Mizhnarodnoi naukovo-praktychnoi konferentsii, 19-20 veresnia 2013 roku, Lviv / Natsionalnyi universytet "Lvivska politekhnika" [ta inshi]. - Lviv: ArtDruk, 2013.

Kondakov, N. (1975). Lohycheskyi slovar-spravochnyk. Moskva: Nauka. 720 s.

Kuznetsov, S. (2000). Bolshoi tolkovyi slovar russkoho yazyka. Sankt Peterburg: Norynt. $1536 \mathrm{~s}$.

Lavrenteva, O. (2015). Stratehycheskaia hybkost kak neobkhodymoe uslovye ustoichyvoho razvytyia promyshlennoho predpryiatyia // Problemy sovremennoi ekonomyky. № 4: 124-126.

Lepeiko, T., Lepeiko T., Shmatko N. (2012). Teoretyko-metodychni zasady upravlinnia pidpryiemstvom: zabezpechennia hnuchkosti : monohrafiia. - Kharkiv: UIPA. $221 \mathrm{s.}$

Mathiassen, L. and Pries-Heje, J. (2006). Business agility and diffusion of information technology // European Journal of Information Systems. No.15: 116-119.

Sak, G., Taymaz, E. (2004). How Flexible are Small Firms? An Analysis on the Determinants of Flexibility. Working Paper 0416. The Economic Research Forum. http://erf.org.eg/wp-content/uploads/2017/04/0416_final1.pdf 201901 27].

Sambamurthy, V., Bharadwaj, A. and Grover, V. (2003). Shaping Agility Through Digital Options: Reconceptualizing the Role of Information Technology in Contemporary Firms // MIS Quarterly. 27 (2): 237-263.

Shatilova, O. (2010). Otsinka rivnia stratehichnoi hnuchkosti pidpryiemstva / Formuvannia rynkovoi ekonomiky: zb. nauk. prats. - Spets. vyp. : u 2 ch. Ekonomika pidpryiemstva: teoriia i praktyka / M-vo osvity i nauky Ukrainy, DVNZ "Kyivskyi nats. ekon. un-t im. V. Hetmana" ; KNEU, Ch. 2: 195-203.

Shatilova, O. (2014). Kontseptualni polozhennia upravlinnia stratehichnoiu hnuchkistiu pidpryiemstva // Aktualni problemy ekonomiky. № 4: 82-87.

Sherehiy, B., Karwowski, W. and Laye, J.K. (2007), A review of enterprise agility: concepts, frameworks, and attributes // International Journal of Industrial Ergonomics, Vol. 37, No. 5, pp. 445-60.

Simpson A. J., Weiner, E. S. C. (1989). The Oxford English Dictionary, 2nd ed. New York: Oxford University Press

Verdú-Jover, A, Lloréns-Montes, F. J., García-Morales, V. J. (2006). EnvironmentFlexibility Coalignment and Performance: An Analysis in Large versus Small Firms // Journal of Small Business Management. 44(3): 334-349.

Vlajic, J. (2017), Effective Usage Of Redundancy And Flexibility In Resilient Supply Chains. In KS. Pawar, A. Potter, \& A. Lisec (Eds.), Proceedings of the 22nd International Symposium on Logistics (ISL 2017): Data Driven Supply Chains (pp. 450-458). Ljubljana, Slovenia: Centre for Concurrent Enterprise, Nottingham University Business School. 
Volberda, H. W., Verwaal, E., Weerdt, Niels van Der (2006). Ownership structure, organisational flexibility and store performance in retail chains // International Journal of Business Environment. Vol.1. No.3: 268-279.

Weerdt, N.P. van der (2009). Organizational Flexibility for Hypercompetitive Markets (No. EPS-2009-173-STR). ERIM Ph.D. Series Research in Management. Erasmus Research Institute of Management. - http://hdl.handle.net/1765/16182 [2018 12 29].

Weerdt, N.P. van der, Verwaal, E., Volberda, H. (2006) Firm Size, Organizational Flexibility, and Performance: Do Small Firms Have a Competitive Advantage over Larger Firms? (Summary) // Frontiers of Entrepreneurship Research. Vol. 26, Iss. 15, Article 7.

Winter, S. G. (2003). Understanding dynamic capabilities // Strategic Management Journal. 24 (10): 991.

Yarulyna, D. Sh. (2005). Otsenka hybkosty predpryiatyia / Materyaly nauchnopraktycheskoi konferentsyy aspyrantov y studentov «Problemy razvytyia fynansovoy systemy Ukrayny». - Symferopol: TNU ym. Vernadskoho: 274.

Zhukov, B. (2007). Ynnovatsyonnoe obespechenye hybkoho razvytyia promyshlennykh predpryiatyi: teoryia, ynstrumentaryi, realyzatsyia: Avtoref. dys. ... dokt. эkon. nauk: 08.00.05. эkonomyka y upravlenye narodnym khoziaistvom: эkonomyka, orhanyzatsyia y upravlenye predpryiatyiamy, otrasliamy, kompleksamy - promyshlennost.- Krasnodar, 2007. $53 \mathrm{~s}$. 